MESMERISM

AND THE END OF THE ENLIGHTENMENT IN FRANCE 
[To view this image, refer to the print version of this title.] 


\section{MESMERISM \\ and the End of the Enlightenment in France}

\section{ROBERT DARNTON}

HARVARD UNIVERSITY PRESS / CAMBRIDGE, MASSACHUSETTS AND LONDON, ENGLAND 


\section{(C) Copyright 1968 \\ by the President and Fellows of Harvard College All rights reserved}

\section{Printed in the United States of America}

This book has been digitally reprinted. The content remains identical to that of previous printings.

Library of Congress Catalog Card Number 68-25607

ISBN 0-674-56951-2 (paper)

See p. 5 for description of title page illustration. 
TO THE MEMORY OF MY PARENTS AND TO JOHN 